\title{
The typology of the nature values in the mining towns on the examples from the region of the Rybnik Coal Area
}

\author{
Katarzyna Pukowiec ${ }^{1}$, Wojciech Kurda ${ }^{2}$ \\ 1 Department of Regional Geography and Tourism, Faculty of Earth Sciences, University of Silesia \\ Będzińska Str. 60, 41-200 Sosnowiec, Poland, E-mail (corresponding author): kasiapukowiec@poczta.onet.pl \\ 2Department of Tourism and Health Resort Management, Institute of Geography and Spatial Management, Faculty of Biology \\ and Earth Sciences, Jagiellonian University, Gronostajowa Str. 7, 30-387 Kraków, Poland
}

\begin{abstract}
Nature's resources having a usability attribute are nature values - if they are able to provide for human demands that are being exploited. This article relates to the environmental potential of mining and post - mining areas as well as possibilities of its use in the development of tourisms and recreation. An original typology of the nature value and the assessment of the tourist usability of environment of chosen mining towns of the Rybnik Coal Area - Wodzisław Śląski, Radlin, Rydułtowy, and Pszów are presented in this work. The Rybnik Coal Area is situated in the southern Poland, in a south-west part of the Upper Silesian Coal Basin. A geological substratum consists of Carboniferous rocks with a hard coal layer exploited from the end of $18^{\text {th }}$ century, but more intensively in the last half-century. In all of the researched towns, hard coal mining is still running and anthropogenic processes changing the environment are taking place. An inventory of natural resources was performed during the direct field work in the years 2010-2011. The nature values were catalogued in a typological way according to the elements of the environment from which they result, focusing on the mining character of the research areas. Therefore, geologic, geomorphologic, hydrologic and biotic (of flora and fauna) have been highlighted, while climatic values have been omitted intentionally due to the vast issue of the assessment of the bioclimatic zone potential. Additionally, natural and anthropogenic elements were distinguished in each group of the values. Due to a significant degree of anthropogenic transformations of the environment, the analysed area is characterised by low environmental attractiveness; tourism and recreation play a marginal role there. Among the nature values of the analysed towns, the geologic qualities are the most significant ones. Therefore, geotourism is the form of tourist activity suggested to revive the region. The greatest potential for the development of geotourism is shown by Pszów, Radlin, Rydułtowy. The development and popularisation of geoturism should be included in the planning documents of the towns mentioned above. In order to increase tourist movement, it is suggested to mark up so-called academic-didactic paths and to mark geotourist object with appropriate information signs and more importantly with the development of infrastructure serving tourism and recreation.
\end{abstract}

KEY WORDS: nature potential, tourist attractiveness, geotourism, Rybnik Plateau

\section{Introduction}

Nature's resources having a usability attribute are nature values - if they are able to provide for human demands that are being exploited. A desire to develop tourism in a given area is one of the reasons to utilise environmental values - thereby the fit in the set of tourist qualities defined by KOWALCZYK (2001) as a whole of environmental and non-environmental elements being a tourists' object of interest and deciding on the tourist attractiveness of a given place.
Tourist qualities make an area attractive for visitors - it focuses attention, arouses one's admiration and desire (KożUCHOWSKI, 2005). According to SoŁOWIEJ (1992) the attractiveness it the degree in which objectively existing environmental conditions attract tourists, whereas environment usability is the set of features enabling its usage and recreation management. The attractiveness and usability of the environment concur to the tourist (recreational) potential that is the set of features enabling the development of tourism. It depends on many factors - a location 
of the area, transport accessibility, tourist infrastructure, and above all on the occurrence of the tourist qualities because they have a significant influence on the development of tourism.

Tourist values (also called sightseeing), in the most general way, can be divided into environmental values and extra environmental values (cultural and anthropogenic). Among a lot of classifications of tourist values LIJEWSKI ET AL. division (1985) deserves a particular attention. It takes into consideration: values shaped without human interference (peculiarities of fauna and flora, crags and group of rocks, gullies, valleys and gorges, waterfalls, springs and karst springs, caves and grottos, glacial erratics and other geologic objects), qualities created by human (historic parks, museums and environmental collections, botanical gardens, and zoological garden) and other qualities (scenic overlooks, national parks and landscape parks).

The Polish scholarly achievements in research on environmental values and their use in tourism is significant. Theoretical issues and the classification or typology of environment values were presented, inter alia, by WARSZYŃSKA \& JACKOWSKI (1978), LIJEWSKI (1985), KRZYMOWSKA-KoSTROWICKA (1997), KoŻUCHOWSKI (2005). The publications by WARSZYŃSKA (1971), KoWAlczyK (2007), MYGa-PiąTEK \& PYTEL (2011) may serve as examples of studies referring to the environmental potential and showing character of a case study. According to WARSZYŃSKA \& JACKOWSKI (1978) the assessment of usability of the environment for tourism should take into account following elements: surface features, surface waters, climate, and plant cover. WARSZYŃSKA (1971), in the article referring to the valorisation of the district of Żywiec, counts relative and absolute altitudes, stagnant waters, forests, and specialist values. KOWALCZYK (2007) while studying tourist values of Pomorze, she discriminates: location and topographic features, climate and bioclimate conditions, surface waters and their tourist values, vegetation and its pharmacological properties, national and landscape parks). KoŻUCHOWSKI (2005), on the other hand, classifies the values according to environment elements: terrain (the qualities are inter alia: absolute altitude, basins, gorges, hills, plateaus), geological structure (e.g. glacial erratics, eskers, drumlins, cuestas, karst, occurrence of gemstones, fossils), surface waters (seas, lakes, and rivers), vegetation (protected species, relicts, endemites, nesting-sites, forest ecosystem), fauna (qualities favourable to fishing, horse riding, and bird watching) as well as air, weather, and climate (qualities are e.g. air composition, sunshine duration, bioclimate, oceanic climate). The classification according to the values was suggested by KRZYMOWSKA-KOSTROWICKA (1997) as well. She has extracted values of: lithosphere, hydrosphere, atmosphere, pedosphere, fitosphere and zoosphere. A similar classification is presented by MYGA-PIĄTEK \& PYTEL (2011) in relation to Silesian voivodeship where hydrologic, geologic, geomorphologic and biologic qualities are highlighted.

This article relates to environmental potential of mining and post-mining areas and the possibility of its use in the development of tourism and recreation. The aim of this work is to show the typology of natural resources and the assessment of the tourist usability of the environment of chosen mining cities from The Rybnik Coal Area in Poland - Wodzisław Śląski, Radlin, Rydułtowy, and Pszów. Nature's resources in this area have been identified and assessed indicating regions valuable in terms of environment and regions predisposed to the development of tourism.

\section{Study area}

The study area is situated in the southern Poland, in a south-west part of the Upper Silesian Coal Basin, called from the sixties of $20^{\text {th }}$ century The Rybnik Coal Area (Grabania, 1963; RUnGE, 1999). In physical-geographical terms, this area is fully situated on the Rybnik Plateau which is a mesoregion of the Silesian Upland (KONDRACKI, 2010). The Rybnik Plateau rises a few metres above the adjacent regions - the Racibórz Valley in the west and the Pszczyna Plain in the east. The geological substratum consists of Upper Carboniferous rocks with a hard coal seams exploited from the end of $18^{\text {th }}$ century but more intensively in the last half-century. This region administratively belongs to poviat of Wodzisław (the second-level unit of local government and administration in Poland) and covers the area of $97 \mathrm{~km}^{2}$ (Fig. 1). The biggest town is the administrative, commercial, cultural and educational capital of this district, Wodzisław Śląski $\left(50 \mathrm{~km}^{2}\right)$, and then Pszów $\left(20 \mathrm{~km}^{2}\right)$, Rydułtowy $\left(15 \mathrm{~km}^{2}\right)$ and Radlin $\left(12 \mathrm{~km}^{2}\right)$. In each of these towns, hard coal mining is still running and anthropogenic processes changing the environment are taking place.

In the researched towns, multifamily housing estates and single-family house districts prevail. Postindustrial sites cover most of the area. In Wodzisław Śląski there was a "1 Maja" coal mine, after which there are mine buildings, spoil tips, mine infrastructure (car parks, sanitary and administration buildings). Next to the coal mine, a district of multifamily buildings called " 1 Maja" was created. The physiognomy of Radlin is 
dominated by industrial and post industrial areas. There is "Marcel" coal mine which is one of the oldest coal mines in the Rybnik Coal Area. Apart from the mine buildings, "Marcel" also owns spoil tips or railway siding (TOPOGRAPHIC MAP, 1994). There is also a mine-owned coking plant "Radlin" which is one of the biggest unit of this type in the Silesia woivodeship. In the area of Rydułtowy and Pszów there is "Rydułtowy-Anna" coal mine, which was created by joining coal mines "Rydułtowy" in Rydułtowy and "Anna" in Pszów. In the area of Rydułtowy there are wide areas of spoil tips. The realization of the above research aims progressed in few stages. In the first one, the subject literature was read and the information about the environment and its resources was gathered on the basis of a regional scientific publications, data from municipal offices, ecophisiographic studies and data from the Central Statistical Office. The basic stage of research included the stocktaking of natural resources during many territory inspections. The further scientific works included the evaluation of the usability the inventoried natural resources and the processing of the typology. The analysis concludes with an attempt to describe the possibility to use the existing natural resources in tourism. The results were processed with the use of MapInfo Professional 7.5 PL. The research (design and field research) took place in the years 2010-2013.

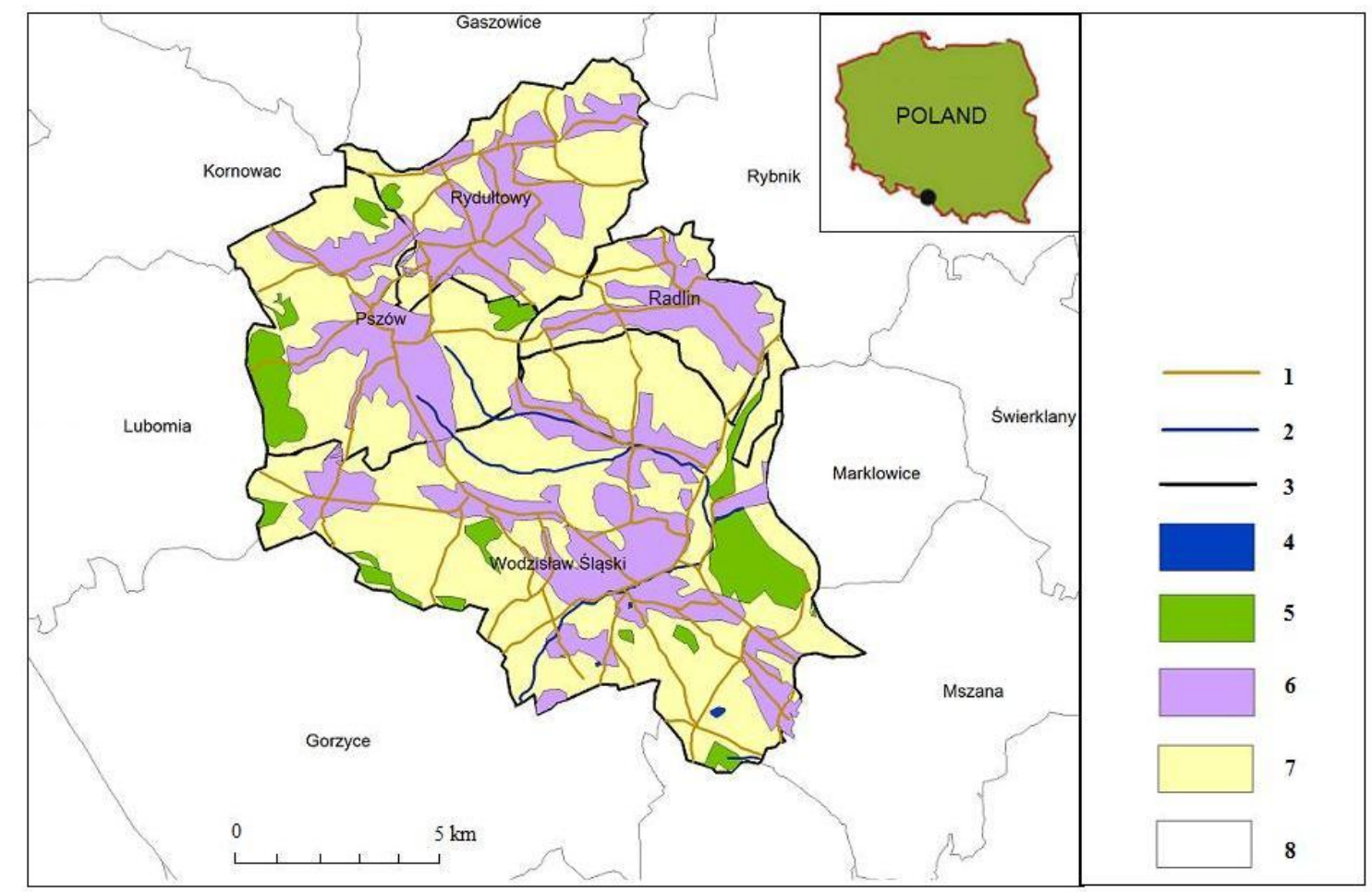

Fig. 1. Study area on the background of using of fields

1 - main roads; 2 - rivers; 3 - border of communities; 4 - water reservoirs; 5 - forests; 6 - built up areas; 7 - remaining fields, mainly agrarian using; 8 - neighbouring communities

\section{Typology of natural values of mining and post-mining regions}

In the following paper, natural values have been presented in a typological way, according to the elements of the environment they stem from. The division used is based upon the typology developed by MYGA-PIĄTEK AND PYTEL (2011) and upon the classification developed by KożUCHOWSKI (2005); it is, however, at the same time, adjusted to specific natural conditions of the investigated region. It is a typology of natural values in mining regions. The following values have been distinguished: geological, geomorphological, hydrological, biotic (fauna and flora); climate values have been omitted, however, due to the vast scope of the issue of the bioclimatic potential of a region. The author's typology of natural values in mining and postmining areas has been presented in Table 1.

Geological values include, among others, glacial erratics as well as rock outcrops and open pits on the surface, both natural (resulting from land forming processes) and anthropogenic (resulting from human activity). Anthropogenic rock outcrops can result from exploiting activities with respect to a particular natural resource (e.g. working pits of usable rocks), as well as during processes not connected directly with mining 
(e.g. terrain modelling during the construction of a railway and bare rocks on railway slopes). Due to the specific character of the investigated area, located within a coal-mining area, there are numerous dumping grounds of gangue (mining waste heaps). Geological values include usable rocks as well - according to the type and the level of the mining opening one can distinguish surface outcrops and open pits, underground mines and boreholes (MATL, 1969).

Table 1 . The typology of the nature values in the mine and post-mine areas

\begin{tabular}{|c|c|c|c|c|}
\hline \multicolumn{2}{|c|}{ Type/Kind } & Origin & & Value \\
\hline \multirow{8}{*}{\multicolumn{2}{|c|}{ Geological }} & \multirow[t]{2}{*}{ natural } & \multicolumn{2}{|l|}{ exposure of rocks } \\
\hline & & & \multicolumn{2}{|l|}{ erratic boulders } \\
\hline & & \multirow[t]{6}{*}{ anthropogenic } & \multirow[t]{3}{*}{ exposure of rocks } & surface mine \\
\hline & & & & underground mine \\
\hline & & & & after drilling \\
\hline & & & dumping ground of gangue & waste heap \\
\hline & & & \multicolumn{2}{|l|}{ excavation of useful rocks } \\
\hline & & & \multicolumn{2}{|l|}{ mines } \\
\hline \multirow{8}{*}{\multicolumn{2}{|c|}{ Geomorphological }} & \multirow[t]{5}{*}{ natural } & \multicolumn{2}{|l|}{ river valley (gorges) } \\
\hline & & & \multicolumn{2}{|l|}{ hills } \\
\hline & & & \multicolumn{2}{|l|}{ canyons } \\
\hline & & & \multicolumn{2}{|l|}{ gates } \\
\hline & & & \multicolumn{2}{|l|}{ thresholds } \\
\hline & & \multirow[t]{3}{*}{ anthropogenic } & \multirow[t]{2}{*}{ concave } & excavation of useful rocks \\
\hline & & & & illegal hard coal well \\
\hline & & & convex & waste heap \\
\hline \multirow{10}{*}{\multicolumn{2}{|c|}{ Hydrological }} & \multirow[t]{4}{*}{ natural } & punctual & springs \\
\hline & & & linear & rivers \\
\hline & & & \multirow[t]{2}{*}{ surface } & lakes \\
\hline & & & & oxbow lakes \\
\hline & & \multirow[t]{6}{*}{ anthropogenic } & punctual & hydrotechnical objects \\
\hline & & & linear & drainage ditches \\
\hline & & & \multirow[t]{4}{*}{ surface } & breeding ponds \\
\hline & & & & water reservors in excavations \\
\hline & & & & water reservoirs in subsidence basins \\
\hline & & & & settling tanks \\
\hline \multirow{18}{*}{ Biotic } & flora & natural & under protection & monuments of nature \\
\hline & & & & surface forms of nature protection \\
\hline & & & & habitats of species under protection \\
\hline & & & not protected & curious trees, dendrological curiosities \\
\hline & & & & forest complexes \\
\hline & & & & Rare/unique associations of forest vegetation \\
\hline & & & & Rare/unique associations of non-forest vegetation \\
\hline & & anthropogenic & cultur parks & \\
\hline & & & dendrological gardens & \\
\hline & & & palm houses & \\
\hline & fauna & natural & under protection & surface forms of nature protection \\
\hline & & & & habitats SAC (Special Areas of Conservation) \\
\hline & & & & habitats SPA (Special Protection Areas) \\
\hline & & & & birds refuge IBA (International Birds Areas) \\
\hline & & & & habitats of species under protection \\
\hline & & & not protected & ecological corridors in national ecological net - ECONET \\
\hline & & & & rare species habitats \\
\hline & & anthropogenic & zoological gardens & \\
\hline
\end{tabular}


Landscape forms constitute, as such, natural values that can be used in recreation due to the functions they perform (aesthetic, sporting, therapeutic, educational). Each of the landscape forms is a result of land forming processes that can be seen in the shape, the size and the internal composition (KoŻUCHOWSKI, 2005). Among various landscape forms worth mentioning are the ones that are of greatest value for tourism, having special features that make them unique natural forms or make them attractive due to their external aspect and landscape-forming character. These include river valleys, especially their sections considered as gorges, monadnocks, ravines, gates (vast lowerings between mountain ranges), river bars, and also some anthropogenic landscape forms. Within the area of Upper Silesia the latter is particularly visible because of mining activity.

Hydrological values include punctual, linear, surface objects connected with hydrography. They can be of natural or anthropogenic origin. The anthropogenic values are those that result from human activity, in particular mining activity, but also ones such as aquaculture ponds created by Cistercians and constituting, at the same time, the cultural heritage of the region. Specific values can also include hydrotechnic items of the antiflooding system.

Biotic values have been divided into values of flora and values of fauna. The natural values classified as flora include nature monuments in the form of single trees or alleys, curiosities of dendroflora (exceptional items due to their size and type). There are also surface forms of protecting the nature, conserving floral habitats, habitats of species under strict or partial protection as well as rare species. Among the values not protected by law there are unique complexes of non-forest flora, forest flora and large, dense forest complexes. Cultural parks are a specific floral value, with planned plantings, often of alien or exotic species. Values of fauna have been divided in a similar way to values of flora. The natural values are connected with the existence of forms of nature protection resulting from the Nature Protection Act of April 16, 2004 or the Bird Directive (Directive of the European Council 79/409/EWG dated as of April 2 concerning the protection of birds) and Habitat Directive (Directive of the European Council 92/43/EWG dated as of May 21, 1992 concerning the protection of natural habitats and wild fauna and flora). Anthropogenic values include zoological gardens.

\section{The characteristics of natural values in chosen mining towns}

Major attention should be paid to geological values in the mining area under investigation. In places such as Rydułtowy, Pszów and Biertułtowy there are mines of coal seams formed in the shoreline environment (paralic series), mostly in the areas of mining fields of "Rydułtowy-Anna” mine and of the former mine "Rymer”. The Upper Carboniferous outcrops occur on the slopes of ravines (MATL, 1969) - from below the loess cover are seen the so-called Poręba Beds. In RydułtowySkała there can be seen sandstones of early Upper Carboniferous, classified into paralic series. At this place, a documentation site protecting abiotic components, called "Skałka" was created. They are a form of nature protection under the Nature Protection Act dated as of April 16, 2004. Among the sandstones of paralic beds the majority is fine-grained, built from quartz, potassium feldspars (orthoclase and microcline) and micas (ZNAŃSKI, 1964). The binding agent in the sandstones of Poręba Beds is usually made of loam and, rarely carbonate (MATL, 1969).

Specific type of geological values within the area of Upper Silesia are dumping grounds of gangue by-product of mining exploitation. In RydułtowySkała there is the highest cone-shaped dumping ground in Upper Silesia called "Szarlota”. Its relative elevation is 135 metres, and the peak is at $407 \mathrm{~m}$ a.s.l. The dumping ground was created as a result of the accumulation of the material from the hard coal mine "Rydułtowy", mainly sandstone, mudstone, conglomerates and slates. The total area of "Szarlota”, and of the neighbouring cone, and of the flat dumping site equals 37.8 ha. In Wodzisław Śląski there is a mining training drift of the District Centre of Continuous Training. It is a good imitation of a hard coal dumping site, the biggest of this type in Poland. The item is located several metres below the surface and serves education and touristic purposes (PRZEWODNIK TURYSTYCZNY POGRANICZA, 2005).

Among geological values there are also usable rocks. Besides the hard coal and Pleistocene sedimentary rocks (gravel and sand) within the researched area there are also other usable rocks. There were fine-grained rocks, sometimes coarsegrained Upper Carboniferous sandstones exploited in Rydułtowy and Niewiadom. The rocks were used in building and road construction. In Pszów there is an outcrop of Miocene limestone the rock, however, is of no economic significance. In the area of Kokoszyce, Rybnik and Pszów there is gypsum (KAMIEŃSKI, 1946; GABZDYL \& HANAK, 2005). Crystal 
gypsum and sulphur found within the area of Pszów have been excavated in the 19th century (LIGĘZA ET AL., 1970). The top parts of the upland of the Rybnik Plateau are made of hills whose elevation reaches 250-350 m a.s.l. The Rybnik Hills culminate near Pszów (311 m a.s.l.). Their peaks are around 100 metres higher than surrounding river valleys (Odra and its tributaries). The land relief of the Rybnik Hills is very diversified due to the existence of numerous ravines in the loess cover (DWUCET, 1986).

Anthropogenic forms within the area of Upper Silesia area, most frequently, the result of mining activity - among the most frequent are dumping grounds, and, less frequently - post-mining excavations after the exploitation of clastic rocks. Some of the anthropogenic landforms, because of the material they are built from, can be classified into geological assets. The most important geomorphological value is the mining waste heap "Szarlota" mentioned below, which is the highest point within the entire area of the Rybnik Plateau. Vast dumping grounds of gangue exist also in Radlin, Skrzyszów and Krostoszowice (dumping grunds of a former hard coal mine "1 Maja”).

Water reserves within the investigated area do not meet the condition of being usable for the purposes of tourism (despite numerous potentially available hydrological assets (see Tab. 1). There is only one item that can be considered as a value - a water reservoir named „Balaton” in Wodzisław Śląski - Grodzisk. It functions as a bathing resort with a beach, a rental shop with water equipment and catering facilities.

Despite the place being located within an area of strong human impact on the environment, there are numerous objects classified as biotic values of flora. There have been no values of fauna noticed in that area. Under the Nature Protection Act dated as of April 16, 2004, natural monuments are defined as single items of biotic and abiotic character or groups there of having a special natural value (...) and being characterized by individual features,distinguishing them from other items; trees of considerable size, bushes of domestic and foreign origin. (...). Within the investigated area, there are 24 natural monuments of biotic character, among which most frequent are single trees of domestic species (common beech, smallleaved linden, English oak, Norway maple, and also European ash). Worth mentioning is also a line of 15 champion oaks at ul. Olszyny in Wodzisław Śląski. Most of the natural monuments are located in Wodzisław Śląski - as many as 17, including the line of champion oaks mentioned above. Within the park and within the palace and park complex in Kokoszyce there are 8 trees that are nature monuments, among which there are exotic species. In Rydułtowy there are 7 trees that constitute natural monuments and belong to domestic species. Nature monuments are often also regarded as dendrofloric curiosities. Within the investigated area, there is also a crack willow called "Kazia”, growing near the riverbed of Leśnica in Wodzisław Śląski-Radlin. Its DBH equals $660 \mathrm{~cm}$. Surface forms of nature protection within the investigated area include the buffer zone of Landscape Park "Cysterskie Kompozycje Krajobrazowe Rud Wielkich". Within the said area, however, there are mainly fields and buffer strips having little landscape value. The Landscape Park "Cysterskie Kompozycje Krajobrazowe Rud Wielkich" has been created primarily in order to protect the nature heritage after a long-lasting economic activity of the Cistercians. It also protects ecologically valuable species, habitats and refugiums of plants and animals (mainly birds).

Natural floral values of the investigated area include several quite big, dense forest complexes which despite not having formed model communities of forest flora, by themselves constitute naturally attractive objects. Within a part of Wodzisław Śląski, called Grodzisko, there is a forest complex called Las Miejski, continuing in northern direction until Marklowice. The border between Lubomia and Pszów is made of a large, dense forest complex in which there is a hill fort coming from the Early Middle Ages and the ruins of a castle on Kotówka.

Floral values of anthropogenic origin include cultural parks that are artificially composed plant comunities, often including domestic and exotic species. Of greatest ecological value is a park in Kokoszyce. The landscape park together with a palace have been listed on the register of the monuments of Silesian voivodeship. The total area of the park equals 30 ha and there are numerous samples of old trees, including 8 natural monuments. There are exotic species growing in the park: rhododendrons, impressive samples of aesculus and tulips (PORWOŁ, 2007). The area of the park is covered by oak-hornbeam and riparian forests of almost a natural character; however, there are also aquatic complexes and rushes and green areas developed by humans (BŁASZCZYK \& STEBEL, 1996). All natural values have been described briefly in Table 2, and their localisation has been demonstrated in Fig. 2. 
Table 2. Nature values in the mining towns - Wodzisław Śląski, Rydułtowy, Pszów and Radlin

\begin{tabular}{|c|c|c|c|}
\hline No & Name of value & Kind of value & Location \\
\hline \multicolumn{4}{|c|}{ GEOLOGICAL VALUES } \\
\hline 1. & Exposure of the Paralic Beds & Rocks exposure & $\begin{array}{l}\text { Mining field „Rydułtowy-Anna”, } \\
\text { Pszów }\end{array}$ \\
\hline 2. & Exposure of the Paralic Beds & Rocks exposure & $\begin{array}{l}\text { Mining field „Rymer”, Radlin- } \\
\text { Biertułtowy }\end{array}$ \\
\hline 3. & $\begin{array}{l}\text { Documentation site of inanimate nature } \\
\text { „Skałka”, exposure of Upper Carboniferous } \\
\text { sandstones (Paralic Series) }\end{array}$ & Rocks exposure & Rydułowy-Skała, Skalna Str. \\
\hline 4. & Mining waste heap „Szarlota” & Dumping ground of gangue & Rydułtowy-Skała \\
\hline 5. & Mining waste heap „1 Maja” & Dumping ground of gangue & $\begin{array}{l}\text { Skrzyszów-Krostoszowice, } \\
\text { Gmina Godów (mining waste heap } \\
\text { belong to „1 Maja” Mine from } \\
\text { Wodzisław Śl. but beyond research } \\
\text { area) }\end{array}$ \\
\hline 6. & $\begin{array}{l}\text { Schooling mine in District Educational } \\
\text { Center }\end{array}$ & Schooling mine & $\begin{array}{l}\text { Wodzisław Śląski, } \\
\text { Gałczyńskiego Str. }\end{array}$ \\
\hline 7. & Quarry of Carboniferous sandstones & Useful rock outcrops & $\begin{array}{l}\text { Borderland of Rydułtowy and } \\
\text { Radoszowy }\end{array}$ \\
\hline 8. & Outcrops of Miocene limestone & Useful rock outcrops & Pszów \\
\hline 9. & Excavation of gypsum and sulfur & Useful rock outcrops & Borderland of Pszów and Kokoszyce \\
\hline \multicolumn{4}{|c|}{ GEOMORPHOLOGICAL VALUES } \\
\hline 10. & Rybnik Hills & Hills & $\begin{array}{l}\text { Northern part of studied area, } \\
\text { Pszów, Rydułtowy }\end{array}$ \\
\hline 11. & Mining waste heap „Szarlota” & Dumping ground of gangue & Rydułtowy-Skała \\
\hline 12. & Mining waste heap of „1 Maja” Mine & Dumping ground of gangue & $\begin{array}{l}\text { Skrzyszów-Krostoszowice, } \\
\text { Godów community }\end{array}$ \\
\hline \multicolumn{4}{|c|}{ HYDROLOGICAL VALUE } \\
\hline 13. & Baths „Balaton” & Lake & Wodzisław Śląski-Grodzisko \\
\hline \multicolumn{4}{|c|}{ BIOTIC VALUES } \\
\hline 14. & $\begin{array}{l}\text { Group of } 8 \text { trees (monument of nature) } \\
\text { of native and alien species }\end{array}$ & Monumental trees & $\begin{array}{l}\text { Park in Kokoszyce, } \\
\text { Wodzisław Śląski, Pałacowa Str. }\end{array}$ \\
\hline 15. & Alley of 15 red oaks (Quercus rubra) & Monumental trees & Wodzisław Śląski, Olszyny Str. \\
\hline 16. & Group of 5 common oaks (Quercus robur) & Monumental trees & $\begin{array}{l}\text { Wodzisław Śląski-Grodzisko, City } \\
\text { forest }\end{array}$ \\
\hline 17. & $\begin{array}{l}\text { Group of } 2 \text { European beechs (Fagus } \\
\text { sylvatica) }\end{array}$ & Monumental trees & $\begin{array}{l}\text { Rydułtowy, neighbourhood of } \\
\text { railroad tunnel }\end{array}$ \\
\hline 18. & $\begin{array}{l}\text { Crack willow „Kazia” (Salix fragilis) on } \\
\text { perimeter } 660 \mathrm{~cm}\end{array}$ & $\begin{array}{l}\text { Monumental tree, } \\
\text { dendrological curiosity }\end{array}$ & $\begin{array}{l}\text { Leśnica Valley, } \\
\text { Wodzisław Śląski-Radlin }\end{array}$ \\
\hline 19. & $\begin{array}{l}\text { Protection zone of the Landspace Park } \\
\text { „Cysterskie Kompozycje Krajobrazowe } \\
\text { Rud Wielkich” }\end{array}$ & $\begin{array}{l}\text { Surface form of nature } \\
\text { protection - buffer zone of the } \\
\text { landscape park }\end{array}$ & Northern part of Rydułtowy town \\
\hline 20. & Deptford pink (Dianthus armeria) & $\begin{array}{l}\text { Locality of protected and rare } \\
\text { plant }\end{array}$ & Western part of Rybnik Plateau \\
\hline 21. & $\begin{array}{l}\text { Moist pine forest (Molinio caerulae- } \\
\text { Pinetum) }\end{array}$ & $\begin{array}{l}\text { Surface form of nature } \\
\text { protection - forest complex }\end{array}$ & $\begin{array}{l}\text { Neighbourhood of Jankowice } \\
\text { Rybnickie }\end{array}$ \\
\hline 22. & „Las Miejski” („City forest”) & Forest complex & Wodzisław Śląski-Grodzisko \\
\hline 23. & Forest on the Kotówka & Forest complex & Lubomia- Pszów, Lubomia commune \\
\hline 24. & Landscape park & Landscape park in city & $\begin{array}{l}\text { Wodzisław Śląski-Kokoszyce, } \\
\text { Pałacowa Str. }\end{array}$ \\
\hline
\end{tabular}




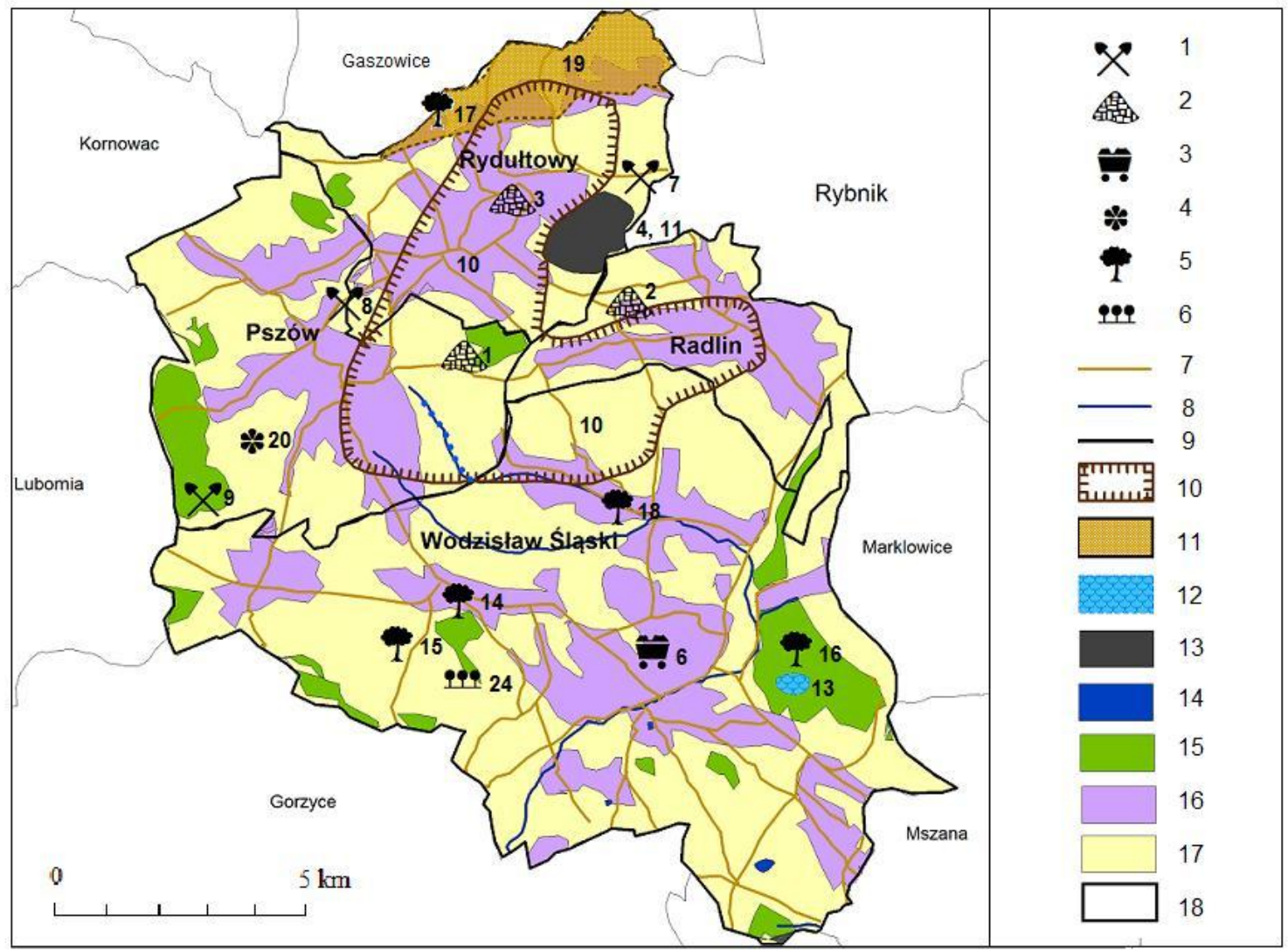

Fig. 2. Localization of nature values according to types in the studied area

1 - anthropogenic outcrop of useful rocks; 2 - natural outcrop of useful rocks; 3 - mine; 4 - habitat of protection flora species; 5 - monument of nature; 6 - landscape park; 7 - main roads; 8 - rivers; 9 - borders of communities, 10 - hills;

11 - surface form of nature protection; 12 - lake; 13 - dumping ground; 14 - water reservoirs; 15 - forests; 16 - built up areas; 17 - remaining fields, mainly agrarian using; 18 - neighbouring communities

\section{The possibilities of using the ecological potential of mining towns}

The development of tourism within the investigated area is now limited mainly to weekend tourism or one-day tourism. Creating the inventory of natural values and their typology as to their usefulness for tourism both indicate, however, that some fragments of the investigated area are characterised by unique ecological and cultural richness. The most attractive and characteristic for the analysed cities of Rybnik Coal Area - Wodzisław Śląski, Pszów, Radlin and Rydułtowy - is the group of geological values and tourism should be developed on their basis. The presence of natural rock outcrops, a documentation post and, above all, of the highest conical spoil tip in Upper Silesia guarantees interest in the form of touristic activity connected with geological resources.

One of the forms of touristic activity are geological expeditions, called geoturism. It is a relatively new form of tourism dedicated to exposing naturally and ecologically attractive items, processes and phenomena, as well as results of human activity. The area of interest of geoturism includes forms, formations, phenomena and processes - both geological and geomorphological, and both natural and those resulting from geological and morphological human activity, as well as tangible and intangible culture connected with it. Geotourism is a branch of cognitive tourism, aiming at experiences, basing on learning about objects and geological processes and living through aesthetic experiences in contact with the (SŁOMKA \& KICIŃSKAŚWIDERSKA, 2004). In a broader sense, it is learning about elements connected with geology and geomorphology of the terrain, that is why in order to practice this type of tourism areas are distinguished that are valuable geologically and geomorphologically. The investigated area, especially Radlin, Rydułtowy and Pszów meet the conditions for the development of geotourism given the existence of outcrops of Upper Carboniferous rocks, rock pits in mining areas, and gangue dumping grounds. In addition, these places are located within morphologically diversified Rybnik Hills. Areas having a high ecological potential resulting from the existence of unique geological and geomorphological values and, because of that, having very good conditions for the development of geotourism, have been presented in Fig. 3 . 


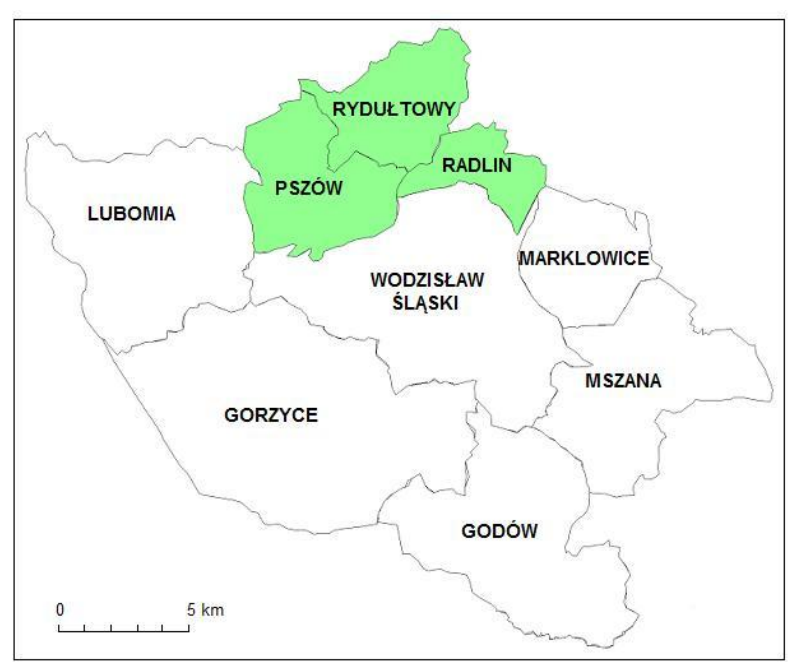

Fig. 3. Areas with good conditions to geoturism development in Wodzisław district (own work)

\section{Conclusions}

The typology of natural values in mining areas includes geological ones as well as geomorphological, hydrological and biotic both of natural and anthropogenic origin. The investigated area, due to a considerable degree of anthropogenic transformation of the environment is characterised by little landscape value, and tourism and recreation play a marginal role here. Among the landscape values of the mining towns of greatest value are geological values, which is why geotourism is a form of tourism connected with landscape values and suggested for activation and development of the region. Of biggest potential for its development are the following towns: Pszów, Radlin, Rydułtowy. The development and popularization of geotourism shall find their place in planning documentation of said towns. In order to increase tourist activity, the following are suggested: marking the geological items described above with adequate information boards and developing the infrastructure that serves tourism and recreation (footpaths and cycling routes, educational paths, catering facilities, promotional material). What is crucial for the development of geotourism within the investigated area is raising the awareness of local community as to the richness of geological values in the place they live.

\section{References}

Błaszczyk D., Stebel A.M. 1996. Zabytkowy park w Kokoszycach. Cenny obiekt botaniczny w województwie katowickim. Przyr. Górn. Śl., 6:16.
Dwucet K. 1986. Zróżnicowanie rzeźby na tle litologii utworów pyłowych Płaskowyżu Rybnickiego. Wyd. Uniw. Śląski, Katowice.

Dyrektywa Rady 79/409/EWG z 2 kwietnia w sprawie ochrony dzikich ptaków.

Dyrektywa Rady 92/43/EWG z 21 maja 1992 roku w sprawie ochrony siedlisk przyrodniczych oraz dzikiej fauny i flory.

Gabzdyl W., Hanak B. 2005. Surowce mineralne Górnośląskiego Zagłębia Węglowego i obszarów przyległych. Przegl. Geol., 53, 9:726-733.

Kamieński M. 1946. Skały użyteczne Dolnego i Górnego Ślq̨ska. Wyd. Inst. Śląskiego, Katowice.

Kondracki J. 2010. Geografia regionalna Polski. Wyd. Nauk. PWN, Warszawa.

Kowalczyk A. 2001. Geografia turyzmu. Wyd. Nauk. PWN, Warszawa.

Kowalczyk A. 2007. Walory turystyczne Pomorza. Wyd. Uniw. Kazimierza Wielkiego, Bydgoszcz.

Kożuchowski K. 2005. Walory przyrodnicze w turystyce i rekreacji. Wyd. Kurpisz, Poznań.

Krzymowska-Kostrowicka A. 1997. Geoekologia turystyki $i$ wypoczynku. Wyd. Nauk. PWN, Warszawa.

Ligęza J. et al. 1970. Ziemia rybnicko - wodzisławska. Wyd. „Śląsk”, Katowice.

Lijewski T., Mikułowski B., Wyrzykowski J. 2002. Geografia turystyki Polski. Wyd. PWE, Warszawa.

Mapa topograficzna, skala 1:50 000, ark. Wodzisław Śląski, 1993.

Matl K. 1969. Stratygrafia górnych warstw brzeżnych w Rybnickim Okręgu Węglowym ze szczególnym uwzględnieniem niecki jejkowickiej. Prace Geol. PAN, Kom. Nauk Geol., Wyd. Geol., Warszawa.

Myga-Piątek U., Pytel S. 2011. Propozycja typologii walorów turystycznych województwa śląskiego. Zesz. nauk. Beskidzkiej Wyższej Szkoły Umiejętn., 1: 100-109.

Porwoł P. 2007. Zespół pałacowo - parkowy w Kokoszycach. Starostwo Powiat. $w$ Wodzisławiu Śląskim. Wodzisław Śląski.

Przewodnik Turystyczny Pogranicza Wodzisławsko-Karwińskiego. 2005. Star. Powiat. w Wodzisławiu Śl., Urząd Miasta Karwina, Wodzisław Śląski, Karwina.

Rozporzq̨dzenie Ministra Środowiska z dnia 27 października 2008. Runge J. 1999. Osadnictwo. [in:] Szajnowska-Wysocka A. (ed.) Studium wiedzy o regionie ślaskim. Wyd. Uniw. Śl., Katowice.

Słomka T., Kicińska-Świderska A. 2004. Geoturystyka podstawowe pojęcia. Geoturystyka. Wydział Geol., Geofiz. i Ochr. Środow, AGH 1, 1:5-7.

Sołowiej D. 1992. Podstawy metodyki oceny środowiska przyrodniczego człowieka. Wyd. Nauk. UAM, Poznań.

Ustawa o ochronie przyrody z 16.04.2004.

Warszyńska J. 1971. Waloryzacja miejscowości powiatu żywieckiego z punktu widzenia atrakcyjności turystycznej. Folia Geogr. Oeconom. 113-136.

Warszyńska J., Jackowski A. 1978. Podstawy geografii turyzmu. Wyd. Nauk. PWN, Warszawa.

Znański Z. 1964. Zarys budowy geologicznej Rybnickiego Okręgu Węglowego [in]: Bojkowski K., Jachowicz A. (ed.) Problemy geologiczne i surowcowe Górnośląskiego Okręgu Przemysłowego. Pol. Tow. Geol., Katowice: 96-112. 